\title{
The Causal Link between Financial Sector and Economic Development: The Case of Kazakhstan
}

\author{
Maya Katenova ${ }^{1}$, William Gissy ${ }^{2} \&$ Zhanat Syzdykov $^{1}$ \\ ${ }^{1}$ KIMEP University, Almaty, Kazakhstan \\ ${ }^{2}$ Georgia State University, Atlanta, Georgia, USA \\ Correspondence: Maya Katenova, DBA, KIMEP University, Almaty, Kazakhstan.
}

Received: November 16, 2016

doi:10.5430/ijba.v8n2p40
Accepted: December 5, $2016 \quad$ Online Published: February 24, 2017

URL: http://dx.doi.org/10.5430/ijba.v8n2p40

\begin{abstract}
This study empirically explores the causal relationship between financial depth and economic growth in Kazakhstan. The specific objective of this study is to investigate whether the causality direction between financial depth and economic growth in Kazakhstan does in fact apply. With this aim, the data from 20 banks operating between 2006 and 2015 was used. This data was obtained from the National Bank of Kazakhstan Statistical Bulletin. Quarterly observations are collected in aggregate form during 1Q 2006 - 4Q 2015 for GDP in level and stock market index value, and individual observations from the 20 largest banks during 1Q 2006 - 4Q 2015 for total lending volume in level in percent point, and total deposit volume in level. These quarterly data are employed in the panel study framework. The results of the study show that banks' lending significantly strongly affects economic growth in Kazakhstan. At the same time, GDP also significantly strongly affects banks' lending. Therefore, there is mutual causality between banks' lending and the economy (Gross Domestic Product) in Kazakhstan. Both the economy and the financial sector do affect each other positively and significantly.
\end{abstract}

Keywords: GDP, economic growth, banks' lending, acceleration, stock market index value, deposits, causality

\section{Introduction}

The role of financial development in economic growth has been widely discussed in previous research. At the same time, the role of economic growth in financial development has been just as widely discussed. This issue of causality between economic and financial growth has attracted worldwide interest, and there are many theories and empirical studies devoted to this particular issue.

Financial development is an important element within the overall economy that affects economic growth. Through the growth of productivity and the efficiency of capital. It also positively affects the accumulation of capital through its effect on the savings rate by altering the proportion of saving [Pagano (1993) and Levine (1997)]. Financial development assumes efficient allocation of surplus funds from lenders to borrowers, which can be achieved through well-functioning financial institutions and markets. Such an efficient allocation of resources may help countries to achieve economic growth and success in a more robust and sustainable way.

Financial impacts on the economy or vice versa may include both direct and indirect financial markets, and in this study, the effects of both equity market and banking sectors on or from the economy are analyzed. Stock investment tends to be pro-cyclical. And pro-cyclical investment behavior may accelerate the development in an economy. However, if investors behave in a counter-cyclical way to exploit the low price advantage during a recession, they may affect the economy in an opposite way, improving economic conditions. A similar scenario can be expected in the banking sector. Bank lending tends to be pro-cyclical, and financial market frictions accelerate economic developments. During recessions, however, if lending is increased by a government's counter-cyclical policy, it may impact the economy in an opposite direction, and the economic situation may recover or deteriorate less severely. Bank lending has been a focal point in the recent debates on the pro-cyclicality of banking regulations after the 2007-08 crisis. Therefore, the study attempts to separate the impacts of direct and indirect financial markets on and from the economy, and to compare the magnitudes of impacts for policy considerations. 


\section{Hypothesis 1}

There is no acceleration (or propagation) of economic variables due to the development of financial variables in Kazakhstan.

\section{Hypothesis 2}

Economic developments in Kazakhstan depend primarily on bank lending. Therefore, the acceleration hypothesis works through an indirect (bank lending) channel.

\section{Literature Review}

The recent global financial crisis has highlighted the importance of the procyclicality of the financial sector. Procyclicality has transformed banks from mitigation mechanisms to amplifiers of changes in economic activity, potentially affecting financial stability and economic growth. The causes of procyclicality can be attributed to many factors, such as deviations from an efficient market hypothesis, Basel-type regulations, accounting standards and leverage. Athanasoglou et al. (2013) The general consensus in the literature is that developed, sound, and functioning financial systems facilitate sustainable economic growth. This conforms to the reasoning of the new endogenous growth theorists. The causal relationship between financial depth and economic growth remains controversial and unclear despite the fact that it has been investigated extensively in economic literature. Arguably, this divergence might emanate from differences in estimation techniques and data. In particular, results seem to be greatly determined by the choice of financial depth indicators. Chukwu and Agu (2009)

As mentioned in Calderon and Liu (2002), economic literature defines financial sector development as the improvement in quantity, quality, and efficiency of financial intermediary services. Financial sector development affects the real growth of output in different ways: the volume of investment increases, and the next to improve is the volume of savings Goldsmith (1969). In recent times, the finance-economic growth nexus has attracted global attention especially in emerging and developing economies. There is still a divergence in views regarding the role of financial intermediaries in facilitating sustainable economic growth in the long-term Tang (2005) mentioned that financial intermediation is seen as one cause of the rapid economic growth in emerging ASEAN economies, as these economies have favored banks over security markets. Moreover, in such developing countries, bank lending is important for firms' investment and working capital, and the credit channel is highly effective. Faris Nasif Al-Shubiri (2012) mentioned that bank lending has a long-term relationship with macroeconomic variables in Jordan. Demetriades et. al. (1996) analyzed the issue of whether financial development affects economic growth in 16 countries; the results of the study were country-specific.

Many authors focus on financial frictions for causes, consequences, and policy recommendations related to financial crises. Examples include Flannery (1981), Hancock (1985), Bourke (1989), Demirguc-Kunt and Huizinga (1999), Saunders and Schumacher (2000) and Njoroge and Kamau (2010), who have obtained diverse and possibly conflicting results. In most studies, banks play the most important role among various financial institutions in providing credits to the economy worldwide, especially in the emerging economies such as those in the CIS region. In these studies, the excessive risk taking of banks (for example, duration and currency mismatching of balance sheet accounts) is singled out as a main cause of financial crisis and of accelerating economic downturns. The banking sector showed a lack of prudence in its balancing of profit motives and safety concerns immediately before the financial crisis. Upon a minor economic shock, however, an excessive pro-cyclical behavior became evident in the banking and regulatory sectors due to the asymmetry of information in the financial market.

Both banking sector and financial market performance are studied as variables, which represent the financial services industry. Besides bank lending, there is an access to fund-raising in the financial market, which is direct finance. For example, Levine and Zervos (1996) argue that well- developed stock markets may be able to offer different kinds of financial services than banking systems and also may provide a different kind of impetus to investment and growth than the development of a banking system alone. The authors mentioned that increased stock market capitalisation may improve an economy's ability to mobilise capital and diversify risk. They also mentioned that various measures of equity market activity are positively correlated with measures of real activity, and that the association is particularly strong for developing countries. The conclusion made by the authors is that "stock market development explains future economic growth."

\section{Methodology}

This study empirically explores the causal relationship between financial depth and economic growth in Kazakhstan. The specific objective of this study is to investigate whether the causality direction between financial depth and economic growth in Kazakhstan does in fact apply. With this aim, the data from 20 banks operating between 2006 and 
2015 was used. This data was obtained from the National Bank of Kazakhstan Statistical Bulletin.

Quarterly observations are collected in aggregate form during 1Q 2006 - 4Q 2015 for GDP in level and stock market index value, and individual observations from the 20 largest banks during 1Q 2006 - 4Q 2015 for total lending volume in level in percent point, and total deposit volume in level. These quarterly data are employed in the panel study framework. These observations were transformed to assure the stationarity of the data set. The GDP and stock market index data are first taken in log form to reduce the impact of heteroscadasticity, and then taken as the first difference between the current and one lagged observations to remove time trend in the data. In addition, some data sets (GDP, Lending, and Deposits) are further differenced in order to eliminate seasonal trends. Nasseh and Strauss (2000) mentioned that taking logs and differences was an important step in order to obtain stationary time series. The authors mentioned that it helps to avoid the complications associated with unit roots and spurious regressions. The research employs a unit root test as a mandatory procedure to check for stationarity.

There are no previous studies on this issue in Kazakhstan. The paper attempts to prove that the dependence of banks on macroeconomic conditions in Kazakhstan should be taken into consideration by bank regulators. During economic recessions, businesses and consumers often default on their loans, even worsening the economic situation, while during economic booms, lenders make more risky loans and thus create a situation in which default probabilities increase.

However, it is also interesting to know the average contribution of an economic variable on each of the 20 largest individual banks' lending behavior after accounting for their unique responses to the independent variables. Besides the basic model, both Random Effect and Fixed Effect models of Panel study can accomodate this analysis. The quarterly observations during 1Q 2006 - 4Q 2015 for the growth rate of GDP (GY), Consumer Price Index (CPI), the Money Supply (MS), quantity of unemployed people Uq as well as individual bank's lending volume, $\mathrm{GL}_{\mathrm{i}}(\mathrm{i}=1 \sim 20$ ) are used for panel estimation. The following panel regression model is employed for the stacked data set of 20 banks in each country.

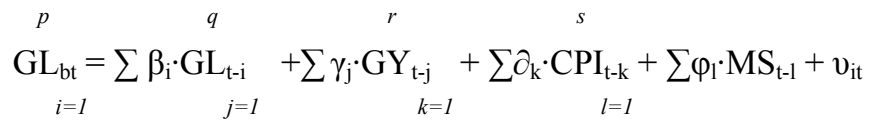

Where $\mathrm{b}$ is bank index, $\mathrm{i}, \mathrm{j}, \mathrm{k}$, and $\mathrm{l}$ are lag index, $\mathrm{p}, \mathrm{q}, \mathrm{r}, \mathrm{s}$ and $\mathrm{t}$ are maximum number of lag (in this study, they are determined as 4 ), and $t$ represents time. The $\alpha, \beta, \gamma, \partial$, and $\varphi$ are parameters to be estimated, and the errors, $v$, are assumed independently and identically distributed.

The following panel regression model is employed in the study to focus on the effect of Gross Domestic Product dependence on banks' lending, stock market, and credit spread.

$$
\mathrm{GY}_{\mathrm{bt}}=\sum \beta_{\mathrm{i}} \cdot \mathrm{GY}_{\mathrm{t}-\mathrm{i}}+\sum \gamma_{\mathrm{j}} \cdot \mathrm{GL}_{\mathrm{t}-\mathrm{j}}+\sum \partial_{\mathrm{k}} \cdot \mathrm{SR}_{\mathrm{t}-\mathrm{k}}+\sum \varphi_{1} \cdot \mathrm{DSP}_{\mathrm{t}-\mathrm{l}}+\alpha_{0} \mathrm{GD}_{\mathrm{t}-\mathrm{l}}+v_{\mathrm{it}}
$$

Where SR represents the stock market index, GD represents bank deposits and DSP reperesents credit spread.

The last panel regression model employed in the study is focused on credit dependence on Gross Domestic Product, Inflation, and the Money Supply.

$$
\mathrm{DSP}_{\mathrm{t}-\mathrm{l}}=\sum \beta_{\mathrm{i}} \cdot \mathrm{DSP}_{\mathrm{t}-\mathrm{i}}+\sum \gamma_{\mathrm{j}} \cdot \mathrm{GY}_{\mathrm{t}-\mathrm{j}}+\sum \partial_{\mathrm{k}} \cdot \mathrm{CPI}_{\mathrm{t}-\mathrm{k}}+\sum \varphi_{\mathrm{l}} \cdot \mathrm{MS}_{\mathrm{t}-\mathrm{l}}+v_{\mathrm{it}}(8)
$$

Besides, Gross Domestic Product, Consumer Price Index, and the Money Supply, an additional macroeconomic variable employed is the quantity of unemployed people in the country. This variable has an anticyclical nature and is negatively correlated with all macroeconomic variables employed.

The responses to the shock in the GDP growth, stock market return, and credit spread are expected to reflect on the estimated coefficients as an average impact for the 20 largest banks' growth rate of lending volume.

Tests for the unit root are applied to the data. As discussed earlier, one of the most important properties of a time series is its stationarity. Unfortunately, nearly all time series exhibit non-stationarity when tested. In most cases, financial time series data are assumed to be non-stationary. Maysami (2004)

A unit root test is employed in order to check whether variables are stationary. Business and economic time series data possess trends, cycles, random walking, and non-stationary behavior. Time series should have some characteristics for the possibility to be stationarized. Such remedies as taking logarithms or deflating the factors can modify them into stationary time series. 
Augmented Dickey Fuller, a more general form of Dickey Fuller, is used for larger and more complicated time series samples. Some methods such as information criteria (including Akaike information criterion, Bayesian information criterion, or the Hannan-Quinn information criterion) or cross-equation restrictions can be used for lag length selection. ADF test statistics gives negative results, and the null hypothesis can be rejected as the t-statistics are increasing in a negative direction. Bayramova (2010)

Critical values are formulated by Fuller (1976), and additional test statistics are provided by Dickey and Fuller (1981) in further papers. Gugaratti (2010)

The Phillips Perron (PP) test along with ADF is a very popular test for financial time series. The main difference between these two tests is that the initial one does not consider any correlations while testing the regression.

The main problem related to PP tests is that they cannot distinguish between stationarity and nonstationarity if the sample size is small and its root is close to a nonstationary value.

According to Bayramova et.al. (2010), the main issues related to VAR are to decide which variables should be included and what lag length is the best for the implementation of the model.

The Panel Data approach is employed as a central model in the study in order to test individual banks' effect on macroeconomic variables, as well as to help increase the number of observations. The main reason is that data that goes far enough is not available in Kazakhstan. This is the main drawback of any type of research in Kazakhstan. Different authors have applied the panel study technique in their research. Bond et. al (2003) used a panel study in order to analyze firms in such countries as Belgium, France, Germany, and the UK. Appergis et.al. (2007) examined whether a long-run relationship between financial development and economic growth exists, employing panel integration and cointegration techniques for a dynamic heterogeneous panel of 15 OECD and 50 non-OECD countries over the period 1975-2000. As a prelude to panel study regressions, a unit root test was employed.

The null hypothesis for unit root according to ADF cannot be rejected both in a $1 \%$ and a $5 \%$ significance level for the majority of variables. The log differenced data was checked for stationarity again. The results prove that the data is stationary, and the null hypothesis of having unit root for ADF and PP is rejected. A stationary condition is an important step before the implementation of such tests as Panel Least Squares and other necessary tests in the study. The results are presented below.

Table 1. Growth in credit spread in Kazakhstan and macroeconomic variables

\begin{tabular}{llllcll}
\hline Variables & Basic model & \multicolumn{2}{l}{ Fixed effect } & \multicolumn{2}{l}{ Random effect } \\
\hline & coefficient & t-statistic & coefficient & t-statistic & coefficient & t-statistic \\
\hline Lag credit spread growth & 5.76 & 5.9876 & 6.08 & 5.9793 & 6.12 & 5.9119 \\
\hline p-value & 0.0001 & & 0.0001 & & 0.0000 & \\
\hline Growth in GDP & -45.76 & -5.8795 & -46.02 & -5.9866 & -49.21 & -5.9902 \\
\hline p-value & 0.0001 & & 0.0001 & & 0.0001 & \\
\hline Growth in inflation & -49.67 & -6.9932 & -50.55 & -8.0123 & -53.59 & -6.7654 \\
\hline p-value & 0.0001 & & 0.0001 & & 0.0001 & \\
\hline Growth in Money Supply & -46.05 & -4.3400 & -45.89 & -4.3902 & -45.72 & -4.6432 \\
\hline p-value & 0.0001 & & 0.0001 & & 0.0000 & \\
\hline Growth in Q u & 3.76 & 4.8754 & 3.80 & 4.8871 & 3.89 & 4.8932 \\
\hline p-value & 0.0001 & & 0.0001 & & 0.0001 & \\
\hline R squared & 0.5032 & & 0.5124 & & 0.5069 & \\
\hline Durbin Watson statistic & 1.90 & & 2.01 & & 1.95 & \\
\hline F statistic & 102.98 & & 101.54 & & 103.02 & \\
\hline
\end{tabular}


The results above demonstrate that credit spread has a negative correlation with all macroeconomic variables, which is supported by the theory. When macroeconomic variables increase, assuming an economic boom, credit spread decreases, which reflects lower risk. When macroeconomic variables decrease, meaning economic downturn, credit spread increases, which implies higher risk exposure. Credit spread is countercyclical, which means that it increases during recessions and decreases during expansion. The explanation of such phenomena lies in the theory, which was mentioned earlier and has been shown to work in Kazakhstan. The results demonstrate that all coefficients are correctly signed. The Durbin Watson indicator is around 2, which means that there is no problem of autocorrelation.

Table 2. GDP growth in Kazakhstan and financial variables including bank performance indicators and financial market performance indicators

\begin{tabular}{|c|c|c|c|c|c|c|}
\hline Variables & Basic model & & Fixed Effect & & Random Effect & \\
\hline & coefficient & t statistic & coefficient & t statistic & coefficient & t statistic \\
\hline Lag GDP growth & 21.98 & 4.9845 & 22.02 & 4.7754 & 22.99 & 4.9988 \\
\hline $\mathrm{p}$-value & 0.0001 & & 0.0000 & & 0.0001 & \\
\hline Lending' growth & 77.82 & 5.5643 & 78.04 & 5.1176 & 79.07 & 5.0234 \\
\hline$p$-value & 0.0000 & & 0.0000 & & 0.0001 & \\
\hline Deposits' growth & 44.98 & 4.9943 & 43.88 & 4.7943 & 43.87 & 4.0943 \\
\hline p-value & 0.0001 & & 0.0000 & & 0.0000 & \\
\hline $\begin{array}{ll}\begin{array}{l}\text { Credit } \\
\text { growth }\end{array} & \text { spread } \\
\end{array}$ & -20.55 & -4.5431 & -20.54 & -4.3654 & -21.03 & -4.2622 \\
\hline p-value & 0.0001 & & 0.0000 & & 0.0001 & \\
\hline $\begin{array}{ll}\text { KASE } & \text { Index } \\
\text { growth } & \end{array}$ & 36.54 & 5.2934 & 35.38 & 5.7789 & 34.998 & 5.3128 \\
\hline R squared & 0.5198 & & 0.5043 & & 0.5106 & \\
\hline $\begin{array}{ll}\text { Durbin } & \text { Watson } \\
\text { statistic } & \end{array}$ & 1.94 & & 1.92 & & 1.99 & \\
\hline F statistic & 87.54 & & 82.04 & & 81.56 & \\
\hline
\end{tabular}

The results above indicate that GDP growth in Kazakhstan is significantly and strongly dependent upon such bank performance indicators as lending growth and that there is weaker dependence in magnitude upon deposits' growth and such financial market performance indicators as KASE Index growth. GDP growth depends more weakly on financial market performance and more strongly on the performance of financial institutions (banks). This means that a finance industry service does in fact affect economic growth in Kazakhstan. Indirect finance plays a relatively more significant role in Kazakhstan in terms of economic development. Such phenomena can be explained by the fact that the country is emerging and that capital markets are not yet developed enough. Moreover, low p-values and significant $\mathrm{t}$-statistics demonstrate that the results are significant enough. A high R-squared coefficient is an indicator of a strong correlation among variables. 
Table 3. Growth in Banks' lending in Kazakhstan and macroeconomic variables

\begin{tabular}{lllllll}
\hline Variables & Basic model & \multicolumn{2}{l}{ Fixed Effect } & \multicolumn{2}{l}{ Random Effect } \\
\hline & coefficient & t-statistic & coefficient & t-statistic & coefficient & t-statistic \\
\hline Lag Banks' lending growth & 25.76 & 4.6845 & 26.06 & 4.7776 & 27.06 & 4.8076 \\
\hline P-value & 0.0000 & & 0.0000 & & 0.0000 & \\
\hline Growth in GDP & 45.78 & 6.0987 & 46.03 & 6.3987 & 45.95 & 6.4124 \\
\hline P-value & 0.0001 & & 0.0001 & & 0.0001 & \\
\hline Growth in CPI & 30.65 & 5.3433 & 31.31 & 5.9856 & 32.06 & 5.9176 \\
\hline P-value & 0.0000 & & 0.0000 & & 0.0000 & \\
\hline Growth in Money Supply & 20.54 & 4.7765 & 22.04 & 4.8021 & 22.06 & 4.8238 \\
\hline P-value & 0.0000 & & 0.0000 & & 0.0001 & \\
\hline R squared & 0.5038 & & 0.5027 & & 0.5031 & \\
\hline Durbin Watson statistic & 2.05 & & 1.94 & & & \\
\hline F statistic & 89.58 & 82.65 & & & \\
\hline
\end{tabular}

The growth in bank lending is explained by the growth in macroeconomic variables. The results are supportive of the fact that bank lending depends on Gross Domestic Product, Inflation, and Money Supply. A high R-square indicator and high coefficients are supportive of the strong dependence of lending in Kazakhstan on macroeconomic variables. Banks' lending is strongly influenced by all macroeconomic variables in Kazakhstan. The results demonstrate low p-values of coefficients, high R-squared coefficient, and significant t-statistic and there is no problem with autocorrelation due to a Durbin Watson statistic of around 2.

The following limitations deserve particular attention. In the panel study there is a limitation that only a ten year period was covered between 2006 and 2015 on a quarterly basis. In the panel study, only large and creditworthy banks were studied in both economies. In the panel study, small, regional banks were totally ignored. Another limitation is that all variables were analyzed quarterly in the panel study, not semiannually or annually. The last limitation is that GDP growth, CPI growth or inflation, Money Supply growth and Unemployment rate growth were the only macroeconomic variables employed. A problematic issue is that in the panel study it was assumed that a small number of banks affect the whole country's GDP, which is also another limitation of this particular study. Small micro variables affect large macro variables in the framework of a panel study.

\section{Conclusion}

Based on the results of the study, we reject hypothesis 1 and accept hypothesis 2 . The study can be developed beyond the banking and financial sector. Other financial institutions such as microfinance or microcredit organizations can be studied and their performance can be employed together with macroeconomic indicators' performance. The same type of research can be implemented in some other emerging countries such as Kyrgyzstan and Belarus. The view of causality hypothesis can be tested in developing and developed countries and the comparative analysis can be implemented as well, which will provide an additional insight into the existing empirical evidence. Further research can employ such variables as an exchange rate or forward rate, and their volatility can be studied together with macroeconomic variables. Further research can concentrate on microeconomic variables such as firms' size instead of macroeconomic variables. A new study can employ other bank-specific variables such as provision for loan losses, earnings before taxes, and operating cash flows. The new study can employ other factors such as human resources in the banking sector and bank efficiency and can be more focused on the role of banks in particular countries studied. There is a great deal of work to be done in this sphere.

\section{References}

Athanasoglou, P., Ioannis, D., \& Manthos, D. (2013). Bank procyclicality and output: issues and policies. Working paper, Munich Personal RePEc Archive.

Bank of England. (2009). The role of macro prudential policy. A Discussion Paper. 
Bayramova. (2010). Empirical test on macroeconomic factors and stock market analysis. Case of Kazakhstani stock market. Lund University, United Kingdom.

Borio, C. (2003). Towards a macroprudential framework for financial supervision and regulation?. Monetary and Economic Department, BIS working papers. https://doi.org/10.1093/cesifo/49.2.181

Bourke, P. (1989). Concentration and other determinants of bank profitability in Europe, North America and Australia. Journal of Banking and Finance, 13, 65-79. https://doi.org/10.1016/0378-4266(89)90020-4

Calderon, C., \& Liu, L. (2002). The Direction of Causality between Financial Development and Economic Growth. Working Papers Central Bank of Chile, No. 184.

Chukwu, J.O., \& Agu, C.C. (2009). Multivariate causality between financial depth and economic growth in Nigeria. African Review of Money Finance and Banking, 7-21.

Demetriades, P.O., \& Hussein, K.A. (1996). Does financial development cause economic growth? Time series evidence from 16 countries.

Demiguc-Kunt, A., \& Huizinga, H. (1999). Determinants of commercial bank interest margins and profitability: some international evidence. The World Bank Economic Review, 13, 430-455.

Faris Nasif Al-Shubiri. (2012). Debt Ratio Analysis and Firm Investment: Evidence from Jordan. International Journal of Economics and Financial Issues, Econjournals, 2(1), 21-26.

Flannery, J.M., \& Protopapadakis, A.A. (2002). Macroeconomic factors do influence aggregate stock returns. Rev Fin, 15, 751-782. https://doi.org/10.1093/rfs/15.3.751

Fuller, W. (1976). Introduction to Statistical Time Series. John Wiley and Sons.

Goldsmith, R.W. (1969). Financial structure and development. New Haven, CT: Yale University Press.

Hancock, D. (1985). The Financial Firm: Production with Monetary and Nonmonetary Goods. Journal of Political Economy, 93(5), 859-880. https://doi.org/10.1086/261339

Hanson, S.G., Kashyap, A.K., \& Stein, J.C. (2010). A Macroprudential Approach to Financial Regulation. Journal of Economic Perspectives, 25(1), 3-28. https://doi.org/10.1257/jep.25.1.3

Levine, R., \& Zervos, S. (1996). Stock market development and long-run growth. World Bank Economic Review, 10(2), 323-339. https://doi.org/10.1093/wber/10.2.323

Maysami, C.R., Howe, C.L., \& Hamzah, A.M. (2004). Relationship between macroeconomic variables and stock market indexes: cointegration evidence from Stock Exchange of Singapore's All-S-Sector Indices. Journal Pengurusan, 24(2004), 47-77.

Nasseh, A., \& Strauss, J. (2000). Stock prices and domestic and international macroeconomic activity: a cointegration approach. The Quarterly Review of Economics and Finance, 40, 229-245. https://doi.org/10.1016/S1062-9769(99)00054-X

Njoroge, L., \& Kamau, W.A. (2010). Macroeconomic developments and banks' behavior in Kenya: a panel data analysis. Savings and Development, 34(2), 191-217. 